\title{
ELECTRO-EJACULATION OF A COMPLETE PARAPLEGIC FOLLOWED BY PREGNANCY
}

\author{
By N. Francois, ${ }^{1}$ M. Maury, ${ }^{1}$ D. Jouannet, ${ }^{2}$ G. David ${ }^{2}$ and J. Vacant ${ }^{3}$ \\ ${ }^{1}$ Centre de Rééducation Motrice, 3 rue Clément Matry, 77 30I Fontainebleau; ${ }^{2}$ Laboratoire \\ d'Histo-Embryologie, Centre d'Etude et de Conservation du Sperme, C.H.U. Bicêtre; \\ ${ }^{3}$ Clinique Urologique, Hôpital Necker, Paris, France
}

Abstract. After having experimented with electro-stimulation on monkeys, the authors have put it into practice with the paraplegic. They report observations on pregnancy of a woman with a complete paraplegic below $\mathrm{T}_{4}$ who was injured $\mathrm{I} 5$ years ago. Nineteen electro-stimulations and seven artificial inseminations were necessary. The electrostimulation is easy and can be repeated at will.

Key words: Electro-ejaculation; Artificial insemination.

AmONGST other aspects of the paraplegic, the genito-sexual problems must be considered by specialists who have their own qualification in this field. For this purpose, in 1972 we started a working group consisting of sterility specialists, urologists, gynaecologists and paraplegists. In the same year, during the Paraplegia Annual Symposium's discussion devoted to these problems, one of us reported the first experience of this working group.

During the following 2 years, experimentation on the monkey (Francois et al., I975) allowed us to progressively improve the electro-stimulation technique with our own apparatus, while doing rectoscopies and sacrificing three of the animals. Having checked that there was no local complication af ter electro-stimulation and, after other authors, had obtained electro-ejaculations with the animal, we started with research in man using the same apparatus and improving the technique progressively.

Now for 3 years, in the genito-sexual clinic which is running in the unit, we have performed I 6 electro-stimulations followed by 63 ejaculations $\left(54^{\circ} 3\right.$ per cent). Out of $3 \mathrm{I}$ patients, $\mathrm{I} 3$ have had an ejaculation, i.e. $4 \mathrm{I} \cdot 9$ per cent.

The publication concerning the details and results of our technique with the analysis of successes and failures is reported elsewhere (Francois et al., 1977). Out of these 13 patients, who have had paraplegia for 2 to 18 years, four had spermatozoa with a mobility equal to or above 30 per cent and a patient, who became a father, was among them.

Observation. This man is a paraplegic of T6 level (below $\mathrm{T}_{5}$ ) following a fracture of $\mathrm{T}_{5}$, spastic, aged 27 years, who was injured 5 years ago, and who was married for 4 years when his wife became pregnant. He is a bookseller in our town.

In the 1965 urological records, we noticed a pyelolithotomy for lithiasis and a noncircular bladder neck resection, taking off eight fragments. In I968 he had a unilateral orchitis. For 7 years and during the electro-stimulation, the urine had been sterile following anti-infectious treatment. The kidneys are normal, the bladder is regular, the bladder neck is closed on the pre-micturition X-rays (Fig. I) and opened on permictional, the vesico-sphincterian function is balanced. 


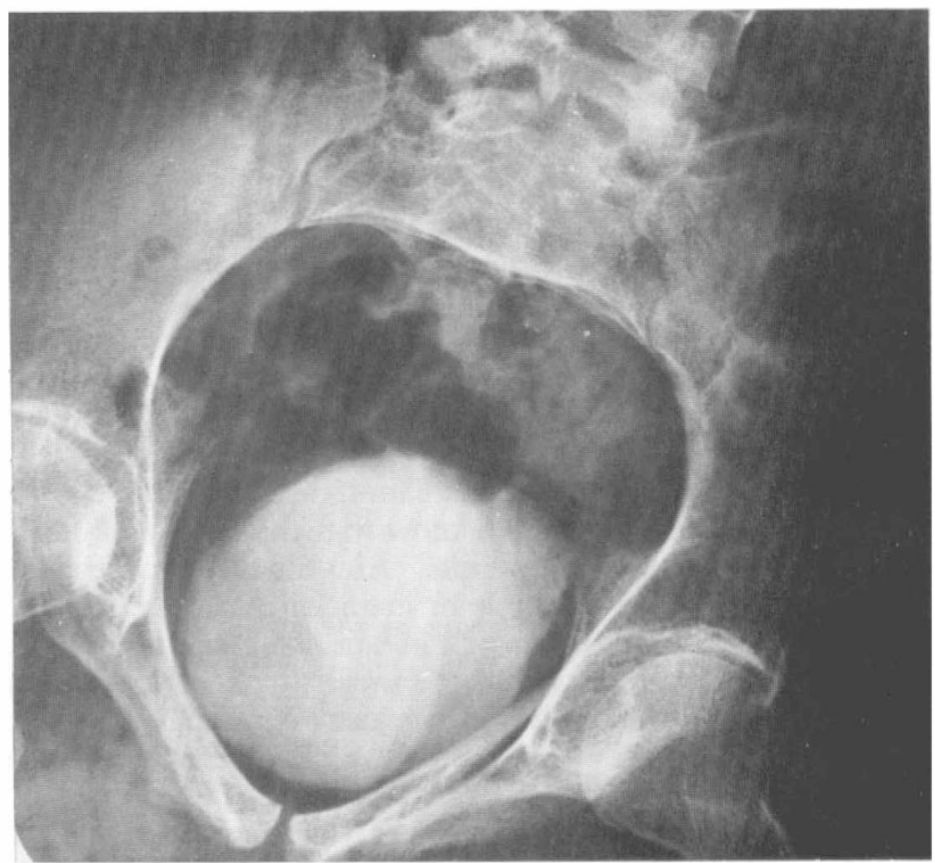

FIG. I

In January 1975, when he first came for a genito-sexual consultation, we noticed he had poor reflex erections and no ejaculation. The LH and FSH tests were respectively at 4.9 and 9.4 Milli-Units $/ \mathrm{ml}$ (normal 5 to 25 and $2 \cdot 2$ to 20 ).

During the electro-stimulation series, we gave treatment for 5 months including Yohimbine, glutamic acid, arginine, Vitamin E. In addition, the patient was given two treatments of Testosterone and Vitamin E for 3 weeks in July 1976 and I week in October 1976.

From February 1975 to October 1976, we performed I9 electro-stimulations and seven artificial inseminations. Table I summarises the results of the first three electrostimulations and of those followed by inseminations.

The only reactions noticed during this course occurred during the first three stimulations. They were perspirations, headaches with raising of the blood pressure maxima from II to I4. They completely disappeared during the I 6 other stimulations.

\section{TABLE I}

\begin{tabular}{|c|c|c|c|c|c|c|c|c|c|c|}
\hline Stimulation number & I & 2 & 3 & 9 & 12 & I5 & I6 & I7 & I 8 & I9 \\
\hline Erection & 0 & 0 & + & \pm & \pm & \pm & + & + & + & + \\
\hline Volume (ml) Ejac. & 0 & 0 & $0 \cdot 2$ & 4 & $\mathrm{I} \cdot 5$ & 0.5 & 2 & 2 & $2 \cdot 5$ & $\mathrm{I} \cdot 5$ \\
\hline Number by $\mathrm{MM}_{3}$ & 0 & 0 & I & 196 & 158 & 120 & 100 & 100 & 100 & 100 \\
\hline $\begin{array}{l}\% \text { in mobility } \\
\text { Morphology }\end{array}$ & 0 & 0 & 0.5 & 20 & IO & 15 & 20 & 20 & 25 & 30 \\
\hline (\% normal) & 0 & 0 & 56 & $?$ & 68 & 70 & 70 & 70 & 75 & 80 \\
\hline Insemination & & & & $x$ & $x$ & $\times$ & $\times$ & $x$ & $x$ & $\times$ \\
\hline
\end{tabular}


The gradual improvement of the quantity and especially of the quality of the spermatic fluid is frequent during the electro-ejaculations in series as if the restarting of the function was bringing about a wakening of the spermatogenesis.

The first consultations proved that the wife had regular periods and was very helpful. The temperature chart was regular and the hysterographia normal. The test of the passage of the cervical glair was positive.

All the artificial inseminations were performed in our Centre by one of us (paraplegist) at the right time according to the temperature chart. The spermatic fluid was instilled in a cervix cap which was left on the cervix uteri.

The sixth and seventh inseminations took place in the same cycle, i.e. on 26 and 28 October 1976. Estelle was born on I6 July I977, weighing 6.5 pounds and is a fine healthy child.

\section{Discussion}

Since the first observations of procreation after intrathecal injections of prostigmine (Guttmann I953, I97I), we know that the spermatic fluid of a paraplegic, even a complete one, may be fertile. And all the paraplegists know procreation cases following natural methods or artificial inseminations after masturbation or electro-vibration. An electro-stimulation performed by Thomas et al. (I975) was followed by a pregnancy, but the infant died. Our observation is the first case of pregnancy brought to term after electro-stimulation.

Obviously the paternity may always be suspicious, even in normal man. A genetic observation is going to be made, but we know it never gives an absolutely positive answer. The placing of a cervix cap gives some guarantee, but the fact that we knew the couple very well, how keen they were on succeeding and moreover, were living near our Centre, contributed a lot in this success.

This observation also proves that a unilateral orchitis may not affect the spermatogenesis. Other examples proved to us that even a prostatitis could not prevent a fecundation, provided that it was not in evolution. The main point consists of having no pyuria in the urine during the insemination.

This observation is very instructive as far as the bladder neck resection is concerned. The numerous ejaculations obtained with this paraplegic demonstrate that this surgery does not necessarily destroy the ejaculation possibilities. Besides, the bladder neck is completely closed on the X-rays. The resection technique probably plays a part in it. This advocates carrying out a resection with fragments rather than a circular resection, with the patients still capable of procreating.

Regarding the gradual improvement of the spermogram, we could meditate on the influence of the drugs. We think it is probably very restricted. There are two kinds of medicines in this field: $(a)$ Those which can be dangerous and bring a glandular aplasia, such as the gonadotrophines, the testosterone. They must be only given in case of hormonal deficiency. That is why it is useful to perform the plastmatics tests of $\mathrm{LH}, \mathrm{FSH}$ and testosterone (the two first ones were normal with our patient, the third one was not performed). (b) Those which are apparently not dangerous such as Arginine, Vitamin E, can be given. At least, they allow to restart or maintain the motivation and perseverance, which are essential to success. We believe much more in the favourable action of the repeated stimulations, i.e. in the important role of the pathology of the nonfunctioning.

We would like to end in recommending electro-ejaculation, the advantages of which were realised a long time ago, for the first time, by Horne et al. (1948). The technique is easy and can be repeated at will. For all those paraplegics having no ejaculation following natural method or local excitation, this is now the best way 
of preventing the pathology of the non-function. In some old cases, it allowed us to improve the spermogram spectacularly. On the other hand we know that in the fecundation by sperm donor, the repetition of artificial inseminations (at least on four cycles) is considered as essential to success. The electro-ejaculation technique is the most suitable for this purpose.

Finally the absence of risks, except with tetraplegics, now allows us to perform it with the new patients. Then, we might be able to know at last if the neurological lesion has or has not an influence on the spermatogenesis.

\section{SUMMARY}

Following experimental studies on monkeys, the authors have used electrostimulation in paralysed male subjects. The electrostimulation to elicit erection and ejaculation is a simple method and can be repeatedly used. However, care has to be taken in tetraplegics.

\section{RÉSUMÉ}

Après l'avoir expérimentée sur le singe, les auteurs ont mis en pratique l'électrostimulation chez l'homme paraplégique. Ils rapportent l'observation d'une grossesse chez la femme d'un paraplégique complet, $\mathrm{D}_{5}$, depuis quinze ans. I9 électro-stimulations et 7 inséminations artificielles ont été nécessaires. L'électro-stimulation est simple et répétable à volonté. Elle peut permettre sauf chez les tétraplégiques de lutter contre la pathologie du non fonctionnement, qui a probablement un rôle important.

\section{ZUSAMMENFASSUNG}

Nach Versuchen mit Elektro-Reizungen beim Affen, haben die Verfasser ihre Kenntnisse am männlichen Paraplegiker ausgeübt. Bei der Frau eines seit I5 Jahren völlig Querschnittgelähmten (D5) konnte eine Schwangerschaft festgestellt werden. I9 ElectroReizungen und 7 Künstliche Befruchtungen waren nötig. Die Elektro-Reizung ist einfach und unbegrenzt wiederholbar. Durch dieses Ferfahren kann außer beim Tetraplegiker, gegen die pathologische Unfähigkeit vorgegangen werden, die wahrscheinlich eine große Rolle spielt.

\section{REFERENCES}

Discussion (1972). Annual Scientific Meeting of the International Medical Society of Paraplegia. (1972). Paraplegia, 10, 242.

Bensman, A. \& KotTke, F. J. (I966). Induced emission of sperm utilizing electrical stimulation of the seminal vesicles and vas deferens. Arch. Phys. Med., 47, 436.

Francois, N., Maury, M., Vacant, J., Cukier, L. \& David, G. (I975). Etude expérimentale de l'électro-éjaculation chez le babouin. Fournal d'Urologie et de Néphrologie, 7, 533.

Francois, N., Maury, Cukier, J., Jouannet, D. \& David, G. (I977). L'électro-éjaculation chez le paraplégique. Premiers résultats et première grossesse. Forum Européen sur la Sexualité des Handicapés Physiques, Bruxelles (A paraitre).

Guttmann, L. (1953). Sexual disturbances. In British Medical History of World War II, Vol. Surgery, 482. H.M.S.O., London.

Guttmann, L. \& Walsh, J. J. (I97I). Prostigmin assessment test of fertility in spinal man. Paraplegia, 9, 40.

Horne, H. W., PAull, D. P. \& Munro, D. (I948). Fertility studies in the human male with traumatic injuries of the spinal cord and cauda equina. New England f. Med., 239, 959-96I.

Rowan, R. L., Howley, T. F. \& Nova, H. R. (1962). Electro-ejaculation. F. Urol. (Baltimore), 87, 926.

SPIRA, R. (I958). Artificial insemination after intrathecal injection of neostigmine in a paraplegic. Lancet, $\mathbf{1}, 670$.

Thomas, R. J. S., McLeish, G. \& McDonald, I. A. (I975) Electro-ejaculation of the paraplegic male followed by pregnancy. Medical fournal of Australia, 2, 798. 